\title{
FORMS OF MANAGEMENT IN AGRICULTURE IN UZBEKISTAN: SCIENTIFIC AND THEORETICAL BASIS OF ITS EFFECTIVENESS
}

Dilorom Tadjibaeva, Tashkent Financial Institute, o_yuldashev@hotmail.com

\begin{abstract}
During the early years of independence (1990s), agricultural and institutional changes in Uzbekistan were made based on the specific characteristics of our country. During transformation, almost nothing has changed in terms of effectivity in regards to transformation of state farms to collective farms still did not make these farms profitable. Only with the formation of dehkan farms (a form of individual farming) after 2004 did agricultural entities started becoming profitable. How can this be explained? Why are these agricultural forms of management more efficient and coincide with the mentality of our population? In this article, using the neo-institutional theory, we have discussed these questions in an attempt to answer these questions by justifying a theoretical point. This theory shows that major issue property rights and transaction costs play main role in the definition of forms of farms management. Statistical analysis of transaction costs and local specifics resulted in a conclusion that the dehkan farming form has significant advantages.
\end{abstract}

UDC Numbers: $332.1-6,332.8,334,338.2$, DOI: $10.12955 /$ cbup.2013.14

Key words: agriculture, farm, farm household, cooperation, dehkan, shirkats, neo-institutional theory, list of Onore, efficiency, transaction cost, labor motivation

\section{Introduction}

The acute question about the justification of the agriculture sector is long term arose. On the one hand, it involves a return to the traditional evolutionary (Chayanov, 1989) approach. On the other hand, it allows turning on a purely economic process in a broader context of socio-economic, political and cultural change by using the economic analysis of research methodologies (Nesterenko, 2002).

The use of theoretical tools to analyze the interaction of people's economic behavior with the institutional environment and the laws governing the development of the economy's institutional structure in the framework of institutional-evolutionary trends in economic science has experienced a new birth for the last two or three decades. But, in Uzbekistan, due attention has not been paid in this regard.

The use of this tool for the analysis of contemporary problems within the agricultural sector would help to find answers to pressing questions, namely, in identifying effective long-term development strategies during the transition period. 
- Can we adapt to the changing socioeconomic situation of post-Soviet collective farms and traditional family type farms in rural areas? What are the best ways and methods to reform them?

- Which institutions can contribute economic growth in rural areas and which cannot? How to change the institutional environment in order to accelerate the process of socioeconomic development within the agricultural sector?

- What is the role of government in the formation of an effective institutional structure in rural areas? How can the social and economic activity of the rural population can be improved? How to make the people actually interested to participate in the process of agricultural sector reforms?

\section{Local specifics of agricultural reform in Uzbekistan}

The main purpose of all the transformations in rural areas is to educate owners interested in their own work and to grow up hard working and entrepreneurial farmers. History reveals that, in rural areas, property owners can ensure efficient use of land and other resources.

During the process of agrarian reforms in Uzbekistan, following state of affairs has been taken into account: Firstly, a) agricultural products are produced mainly in irrigated areas; this requires powerful irrigation systems, and b) more than half of the land used has varying degrees of salinity and requires continuous irrigation. So there arises a question about the ownership of irrigation and drainage systems.

Secondly, according to historical religious belief, the land belongs only to God. Our ancestors, following this belief, developed the rights of land usage. In contrast to Europe and North America, Central Asia never had a full sense of private ownership of land. The land was leased to individualsdehkan farmers. They were able to collateralize, and could sell this right to use or used this right themselves. Rents of the land ranged from a fifth to half of the crop.

Thirdly, there was a shortage of land in Uzbekistan as only 9.1 percent of the total land area was suitable for cultivation. High population growth combined with limited amount of agriculture land lead to severe shortage of land. About $65 \%$ of the population lived in rural areas. In this situation, the introduction of private property could have been a cause of social instability.

Fourthly, there is need of free capital mobility. Free movement of capital is ensured by public ownership of land because private ownership creates a border for its free application (Dobrynin \& Tarasevich, 2004). Therefore these local features were taken into account during agrarian reforms.

Based on the ownership of land, the owner and the land user are two types of subjects in market agricultural economy. A preference was given to the second type and state-owned land transferred to long lease. On this basis, the institutional agriculture reform was held. Since the beginning of institutional reforms in 1993, state agricultural enterprises were transformed into various non-state sectors. As a result of the currency reform of 1994, after the breakup of the USSR, many entities lost a significant part of their working assets. The default became a form of preserving any sort of backward economic structure. The attempts were made to restructure and reorganize collective farms.

Many farms were on the brink of bankruptcy or already bankrupt. In the late 1990's and early 2000's, the global price of cotton, which is an essential agricultural product in Uzbekistan, declined. In 2002 
(compared to 1995) prices fell by a factor of two. Although in the successive years prices did increase slightly, yet the increase in prices of agricultural inputs was higher. Naturally, such a pattern impacted the domestic market.

Table 1: The structure and change of business entities in the agriculture of Uzbekistan

\begin{tabular}{|l|c|c|c|c|c|c|c|}
\hline & \multicolumn{7}{|c|}{ Years } \\
\cline { 2 - 8 } & 1990 & 1998 & 2000 & 2003 & 2008 & 2009 & 2010 \\
\hline State Farms & 1108 & - & - & - & - & & \\
\hline Collective Farms & 940 & 1299 & - & - & - & & \\
\hline Shirkats & & 426 & 1643 & 1784 & 115 & 115 & 115 \\
\hline Agricultural enterprises & 111 & 64 & 563 & 237 & & & \\
\hline Farms & - & 440 & 919 & 19155 & 219900 & 107356 & 80628 \\
\hline $\begin{array}{l}\text { Dehkan Farms (in } \\
\text { thousands) }\end{array}$ & & 3137 & 3293 & $\ldots$ & 4632 & 4722 & 4744 \\
\hline
\end{tabular}

Sources: Uzbekistan in figures (1991), Economic Survey for 1991-1996 (1996), Economy of Uzbekistan (2009), Agriculture of Uzbekistan (2011)

The objective of the establishment of a market economy cannot be achieved without the corresponding changes in the institutional structure. In Uzbekistan, about $65 \%$ of the population is living in rural areas. Currently about 3 million people are employed in agriculture sector. This represents more than a quarter of (Uzbekistan's) total employment. The reforms in agriculture sector must ensure effective functionality of market mechanisms in day to day life within Uzbek villages. In the process of reformation of agrarian economy needs an institutional transformation. The changes in the agriculture market also have critical importance. Furthermore, the change in agriculture is to explore new forms of organization and introduction of modern management techniques and these changes can ensure efficient use of land, water, material and financial resources.

It may be assumed that, in Uzbekistan during 1991-2003, effective forms of economic activity have been pursued that could meet the requirements of modern farming and the mentality of our people. Farmers, farms and agricultural enterprises (shirkats) have been chosen based on the characteristics of our country and the world's experience.

The Uzbek economy is a Dehkan economy - a small-scale family farm. Production and sale of agricultural products is based on the family's personal labor and processing on the land goes to the head of the family as a lifetime inheritable possession. Activity in such an orchard farm can be conducted (an option of its members) as an incorporated or unincorporated entity. By law, dehkan farms are allocated 0.35 hectares irrigated land, 0.5 hectares rain fed land, and not more than 1 hectare of un-irrigated land in steppe zone.

Farm is an independent economic incorporated entity, based on the joint activities of farm members, running commercial agricultural production using land granted in a long-term lease. Currently, land allocated to farmers is based on competition for long-term leases of 30 to 50 years. Agricultural enterprises (shirkats), legal incorporated entities, own property in land, as well as other assets carry out the production of crops and livestock and manage agricultural production.

Currently in Uzbekistan, there are 80628 (after optimization 66134) farms, about 4744 thousand farmer households, and 115 agriculture enterprises. More than half of these farms specialize in the 
production of cotton and grain, occupy about $67 \%$ of cultivated land, and take up an average of 106.3 hectares of land. Only $8.3 \%$ of farms specialize in livestock and have on the average 205 hectares of land. More than $40 \%$ of farms grows vegetables, melons, fruits, grapes, etc. and has an average of 13.1-23.5 hectares. Dehkan farms occupy on the average of 0.2 hectares of land. Agricultural enterprises (shirkats) occupy on the average of 1,242 hectares of land.

As well known and one of the important indicators of efficiency in agriculture production is the level of productivity. Therefore, the crops that grow in all forms of enterprises have been chosen for the comparison of different agriculture enterprises.

Table 2: Level of crop productivity (for 2010) for different types of management

\begin{tabular}{|l|c|c|c|c|c|c|}
\hline & $\begin{array}{c}\text { Wheat, } \\
\text { c/he }\end{array}$ & $\begin{array}{c}\text { Rice, } \\
\text { c/he }\end{array}$ & $\begin{array}{c}\text { Potato, } \\
\text { c/he }\end{array}$ & $\begin{array}{c}\text { Fruits, } \\
\text { c/he }\end{array}$ & $\begin{array}{c}\text { Melons, } \\
\text { c/he }\end{array}$ & $\begin{array}{c}\text { Grape. } \\
\text { c/he }\end{array}$ \\
\hline Total & 48.2 & 36.0 & 198.4 & 87.2 & 191.0 & 85.2 \\
\hline Including & \multicolumn{5}{|l|}{} \\
\hline $\begin{array}{l}\text { Agriculture } \\
\text { shirkats) }\end{array}$ & 34.4 & 27.3 & 135.0 & 40.6 & 171.7 & 78.3 \\
\hline Farms & 47.3 & 35.3 & 166.3 & 73.4 & 174.3 & 72.3 \\
\hline Dehkan economy & 55.9 & 49.4 & 206.1 & 109.9 & 210.6 & 110.0 \\
\hline $\begin{array}{l}\text { Level of productivity, the } \\
\text { farmer households in\% }\end{array}$ & \multicolumn{5}{|l}{} \\
\hline Agriculture enterprise & 162.5 & 180.9 & 152.6 & 270.6 & 122.6 & 140.5 \\
\hline Farms & 118.2 & 140.0 & 124.0 & 149.7 & 120.8 & 151.3 \\
\hline
\end{tabular}

Source: Agriculture of Uzbekistan (2011)

These tables demonstrate the highest productivity in farmer households, followed by farms. The analysis of the data in the Table 2, It can be concluded that the farmer facilities are effective than that of shirkats. In 2000, agricultural enterprises using $72.7 \%$ of the cultivated area produced $28.9 \%$ of the gross agricultural output while dehkan and farms using $27.3 \%$ of the cultivated area produced $71.1 \%$ of the total output. By 2010, these farms of the economy, already occupied $97 \%$ of cultivated land and produced $97.9 \%$ of the gross output.

Table 3: The share of agriculture in GDP and its average annual growth rate (in percentage)

\begin{tabular}{|l|c|c|c|c|c|c|c|}
\hline \multirow{2}{*}{ Indicators } & \multicolumn{8}{|c|}{ Years } \\
\cline { 2 - 9 } & 2000 & 2005 & 2006 & 2007 & 2008 & 2009 & 2010 \\
\hline Average annual GDP growth & 103.8 & 107.0 & 107.5 & 109.5 & 109.0 & 108.1 & 108.5 \\
\hline The share of agriculture in GDP & 30.4 & 25.0 & 24.0 & 21.7 & 19.4 & 18.0 & 17.5 \\
\hline $\begin{array}{l}\text { Average annual growth of the gross } \\
\text { agricultural production }\end{array}$ & 103.2 & 105.4 & 106.7 & 106.1 & 104.5 & 105.7 & 106.8 \\
\hline
\end{tabular}

Source: Economy of Uzbekistan (2009); Major trends of economic and social development of Uzbekistan for years of independence (1990-2010) and forecast for 2011-2015 (2011)

These data confirm that a steady growth in agricultural production had been achieved. Dehkan and farms are an effective form of farming. Mainly dehkan farms occupying only $2.5 \%$ of the cultivated 
area produce more than $62 \%$ of the gross agricultural output. They mainly grow labor-intensive products, and the labor plays dominant role in the livestock production on these farms. They fit into a mentality, complex traditional informal rule-set and institution that is slow and difficult to change. In contrast to the informal institutions the formal institutions can change quickly. The informal institutions are not responsive to the changes and to change them is difficult. Furthermore, the adequacy and effectiveness of performance of the formal sector is largely dependent on how they are "in tune with the rules of day-to-day law" (Timofeev, 2001).

\section{Scientific and theoretical based criteria for the effective management of agriculture entity forms}

The question arises in mind is that can it be explained and justified from a theoretical point of view? It can only be explained, in our opinion, based on non-institutional theory. In determining an advantageous form of farms, we should follow two criteria: a) property rights, and b) transaction costs.

Exact definition or 'specification' of property right is needed to adjudge the effective market operation in terms of property rights. If the property rights are more clearly defined and better protected then there would be a closer relationship between the actions of economic agents and their prosperity. Thereby, the specification pushes to render the most effective economical decision. It is particularly important whose bundle of rights, the so-called "list of Onore. ${ }^{1 "}$

A specification of property rights ensures a sustainable economic environment. Individuals' farms have stable expectations about other agents of economy. It is a necessary condition for an effective functionality of the market mechanism as a whole. The logic here is that property rights create the conditions for economic entities matching the expected costs and rewards of their actions. The redistribution of property rights is accompanied by a shift in the system of economic incentives and these shifts cause changes in the economic behavior of (its) subjects.

Bundle of rights, so-called "list of Onore" according to the law "On the orchard farm", is wholly owned by dehkans and the farms. Lifetime inheritable use of land in dehkan households creates certain guarantees for capital investments in agriculture. The family farm peasants are real masters, and there prevails the owner's motivation. An owner's motivation stems from the direct long-term interest of the household in the final results of operations as a prerequisite for the welfare of the family, not only in the present but as well as in the future. It is supported by the majority of peasant families where labor and farm holding is based on good faith, mutual trust and confidence in the partners of the joint management and the predictability of partners inherited from generation to generation.

\footnotetext{
${ }^{1}$ As Eggerson (2001) writes regarding to the theory of property rights, there are proposed different combinations of discretional rights, which cover the full variety of human relations that arise in the implementation of ownership rights which identifies the following rights (I) The right to use an asset (the user right), which determines the individual's option utilization, in some cases right down to its physical alteration or destruction is legitimate; (ii) The right to receive benefits from the wealth and enter into contracts with other individuals in terms of earn benefits; (iii) The right to transfer ownership to the benefit of the other party, i.e., the right to dispose of or sell the good (Nesterenko, 2002).

An extended list of all owner rights, consisting of eleven "bunch" and that has become a textbook today, was proposed in 1961 by A. Honore. It includes (i) the right of ownership, i.e., exceptional physical control of the good; (ii) the right of user, that is, the right to receive benefits utilizing directly the good; (iii) the right to control, i.e. to make decisions on how and who should use the good; (iv) the right to the benefit gained from the previous personal owning or permit others to use etc.
} 
"On farms" (except items 2-3), "bundle of property" is wholly owned by the farmers and their families. They fulfill the state order for cotton and grain. Since the revenue in dehkan farmer households is wholly owned by themselves, whereas in farms most of the revenue is owned by farmers, there is hidden deep motivation for efficient farming. It is also driven by competition law, which makes everyone win based on the instinct of self-preservation.

According to the Research Institute of Soil Science and Agricultural Chemistry, since 1992, the average bonitet rate decreased 3 points and now stands at 55. Scientifically and experimentally, it has been confirmed that a rise in bonitet quality of land by 1 point increases the amount of cotton yield by $0.4 \mathrm{t} / \mathrm{ha}$ and grain yield by $0.6 \mathrm{t} / \mathrm{ha}$ (Umurzokov, Toshboev \& Toshboev, 2008).

\section{Farmers are not interested in improving the bonitet quality of the land}

Firstly, although the lease is long-term but it is based on contract, whereas, the bonitet rate is renewable each year. An increase of soil bonitet results in increase of tax and production claim in the contract, which is not desirable for farmers. Moreover, in case of a break in lease contracts or services, a farmer is not able to return sources spent to improve the quality of the land. There are, however, some mechanisms for an early termination of lease agreements, transfer of land on a competitive basis and bankruptcy of inefficient farms. The efficiency and legal validity is not always perfect and transparent. Farmers also do not have an independent right to resell the lease. Another important factor is an implementation of crop rotations. According to our scientists' research, various schemes of crop rotations have been developed: 3:7, 3:6, 3:5. Especially note the valuable Lucerne: cotton crop rotation. But for a while they were not implemented properly, especially by the farmers who were to fulfill the state order planted for the entire area by only cotton and grain.

Therefore in our opinion Uzkomzemgeodezkadastr (name of a regulatory regarding to land propriatory) should be studied thoroughly and after every five years the condition and quality of land should be estimated. This information should be provided to dehkans, farms and shirkats on regular bases. The state orders for cotton and grain should depend on the bonitet-points-quality of land and water resources.

There is a need to develop and implement changes in the legislation that clearly define the "rules of the game". The rules and regulations, about the transfer of land to those who wish to farm effectively, must be transparent and clear. The recovery of the capital cost must be taken into account to improve the quality of land based on the bonitet-points-quality for the previous user. A crop rotation scheme proposed by our agrarian scientists should be implemented. Government should promote the flexible accommodation of crops.

In a family farm system, farmers are real owners and there prevails an owner's motivation in these forms. An owner's motivation stems from the direct long-term interest of the household in the final results of operations as a prerequisite for the welfare of the family, not only in the present, but in the future. It is reinforced by most farming families' characteristics and passed on to the generations to come. The ethics and management based on good faith, mutual trust and confidence in the partnership of joint management are rooted in the minds and actions of the members of family labor ethics. In agricultural enterprises, property rights (a "bundle" of property) are prorated among the members of a shirkat, and the motivation here is already a little different than that in entities with other forms of management. 
Secondly, the transaction costs keep farmers from improving the bonitet quality of the land. One of the founders of neo-institutionalism, R. Couse, is of the opinion that the selection of organizational form and size of company should depend on transaction costs (Coase, 1993 and Coase, 2001). Moreover, transaction costs should be considered on three levels: on the farm, in the market and in the level of political decisions. Intra-farm transaction costs are associated with the monitoring of results and performance of department heads, professionals and workers. It also includes farm managing costs.

Such monitoring, in agriculture, has significant difficulties due to objective conditions. In contrast to the industry it is very difficult and sometimes impossible to determine the contribution of each employee in the production. It is difficult to find whose merit or fault is in a good or bad harvest? Is it a plowman, sower, irrigator or agronomist or the weather? Elucidation of this is related to time separation between labor costs and outcomes. Moreover, the large role of weather conditions is unrelated to any human wishes. So it becomes very difficult to determine the contribution of each employee in the result, it is impossible to create an effective system of incentives, as it is impossible to conduct monitoring to detect at which point, more or less, is promoted to the development of a plant or livestock.

From this point of view, dehkan and private farms have an advantage. Although in private farms, the use of hired labor cannot be ruled out. However, hired labor in such enterprises always has a supporting role and does not have influence on a specific characteristic of a family production. Therefore, in these farms labor motivation is very strong and each family member tries to perform assigned work efficiently and in a timely manner, as well as the requirements of other wage labors.

In these forms of housekeeping, transaction costs are low due to, firstly, the process of labor and management are merged together by the head of the family and/or partly by other family members. Secondly, the management of these farms is conducted on a family hierarchical scheme. As based on international experience and research, such entities are the smallest among small businesses. The reason for such difference lies in the peculiarities of people's motivation and work behavior on these farms.

Transaction costs in the market emerge from a necessity of overcoming certain barriers of entering the market and of the transfer of property rights. Usually there are five such barriers with resulting transaction costs: an information search about the buyers and sellers, negotiation and conclusion of contracts, measurement, a specification and protection of property rights, and an opportunistic behavior in counter parties.

Any act of exchange in neo-institutionalism is understood as an exchange of "bundle of property rights." A contract is the channel of their transfer. It specifies powers and under what conditions they are transferred. Specification of property rights requires expenses, sometimes severe. It is economically justified only if associated costs of its process (they are part of the transaction costs) do not exceed the benefits to accrue. Therefore, the definition of the level and protection of property rights of a particular object for a defined country and a specific period in its development must be based on the balance of costs and benefits associated with their specifications.

The situation can only be properly assessed during the division of property on any goods and resources, as well as establishing and defending the rights of ownership. The study Letter to TFI (2012) shows that farms have a specific cost structure (see Table 4). 
CBU INTERNATIONAL CONFERENCE ON INTEGRATION AND INNOVATION IN SCIENCE AND EDUCATION

Table 4: Farmers' cost structure in producing of raw cotton and grain cereals crops ( in percentage)

\begin{tabular}{|l|c|c|}
\hline & Cotton & Grain-cereals \\
\hline Payrolls & 30.1 & 16.7 \\
\hline Mineral fertilizers & 21.1 & 16.4 \\
\hline Defend costs & 1.7 & 2.6 \\
\hline Fuels and lubricants & 20.3 & 15.9 \\
\hline Seeds & 4.2 & 16.6 \\
\hline Services of MSP(Mechanization service providers) & 11.2 & 18.1 \\
\hline Services of AWC(Association of water consumers) & 1.5 & 1.2 \\
\hline Electricity costs & 0.9 & 0.9 \\
\hline Land taxes & 4.8 & 3.7 \\
\hline Other & 4.2 & 7.9 \\
\hline Total & 100 & 100 \\
\hline
\end{tabular}

Source: Letter to TFI (2012)

The figures in the Table 4 are evident that more than $60 \%$ of the costs are based on contracts. To ensure this service, an appropriate agriculture infrastructure is established. Some transactions can be committed immediately, on the spot, especially in dehkan farms. But very often the transfer of ownership is naturally delayed, creating a long process. In such cases, a contract becomes a sharing promise, thus limiting the future behavior of the parties. Also, these restrictions apply voluntarily. So here, of particular importance is the precise definition of "game" rules.

\section{A Model of linear multivariate regression analysis estimates the gross output in agriculture}

To explorea dependence of outcome per hectare from different service providers, general linear multiple regression is chosen.

For the general multiple regression model:

$$
y_{i}=\beta_{1} x_{i 1}+\beta_{2} x_{i 2}+\cdots+\beta_{p} x_{i p}+\epsilon_{i}
$$

With 4 independent variables

X1-average cultivated area per MSP, ha;

X2-average cultivated area per AWC, ha;

X3- average cultivated area per Fuel and lubricants provider, ha;

X4-average cultivated area per Mineral fertilizers provider, ha;

With dependent variable

$\mathrm{Y}-$ Gross output per hectare of land

There are 6 years of observations. 
CBU INTERNATIONAL CONFERENCE ON INTEGRATION AND INNOVATION IN SCIENCE AND EDUCATION

Table 5: Statistical historical data for simple multivariate regression model

\begin{tabular}{|l|c|c|c|c|c|}
\hline Years & $\begin{array}{c}\text { Gross output from } \\
\text { one hectare } \\
\text { thousand sum / ha } \\
\text { (in 2005 prices) }\end{array}$ & $\begin{array}{c}\text { Average } \\
\text { cultivated } \\
\text { area per MSP, } \\
\text { ha }\end{array}$ & $\begin{array}{c}\text { Average } \\
\text { cultivated } \\
\text { area per } \\
\text { AWC, ha }\end{array}$ & $\begin{array}{c}\text { Average } \\
\text { cultivated area } \\
\text { per Fuel and } \\
\text { Lubricants } \\
\text { provider, ha }\end{array}$ & $\begin{array}{c}\text { Average } \\
\text { cultivated } \\
\text { area per } \\
\text { Mineral } \\
\text { fertilizers } \\
\text { provider, ha }\end{array}$ \\
\hline 2005 & 1071.6 & 3809 & 4465 & 5076 & 4545 \\
\hline 2006 & 1122.6 & 2561 & 2934 & 3603 & 3805 \\
\hline 2007 & 1191.0 & 2248 & 224 & 2985 & 4489 \\
\hline 2008 & 1244.5 & 2250 & 2219 & 2913 & 4310 \\
\hline 2009 & 1315.3 & 2276 & 2178 & 2879 & 4278 \\
\hline 2010 & 1404.7 & 2816 & 2179 & 2904 & 4362 \\
\hline $\begin{array}{l}2005-2010 \\
\text { change in \% }\end{array}$ & 131.1 & 73.9 & 48.8 & 57.2 & 95.9 \\
\hline
\end{tabular}

Source: Uzbekistan in figures (1991); Economic Survey for 1991-1996 (1996); Economy of Uzbekistan (2009); Agriculture of Uzbekistan (2011)

The model has the following features (Table 6).

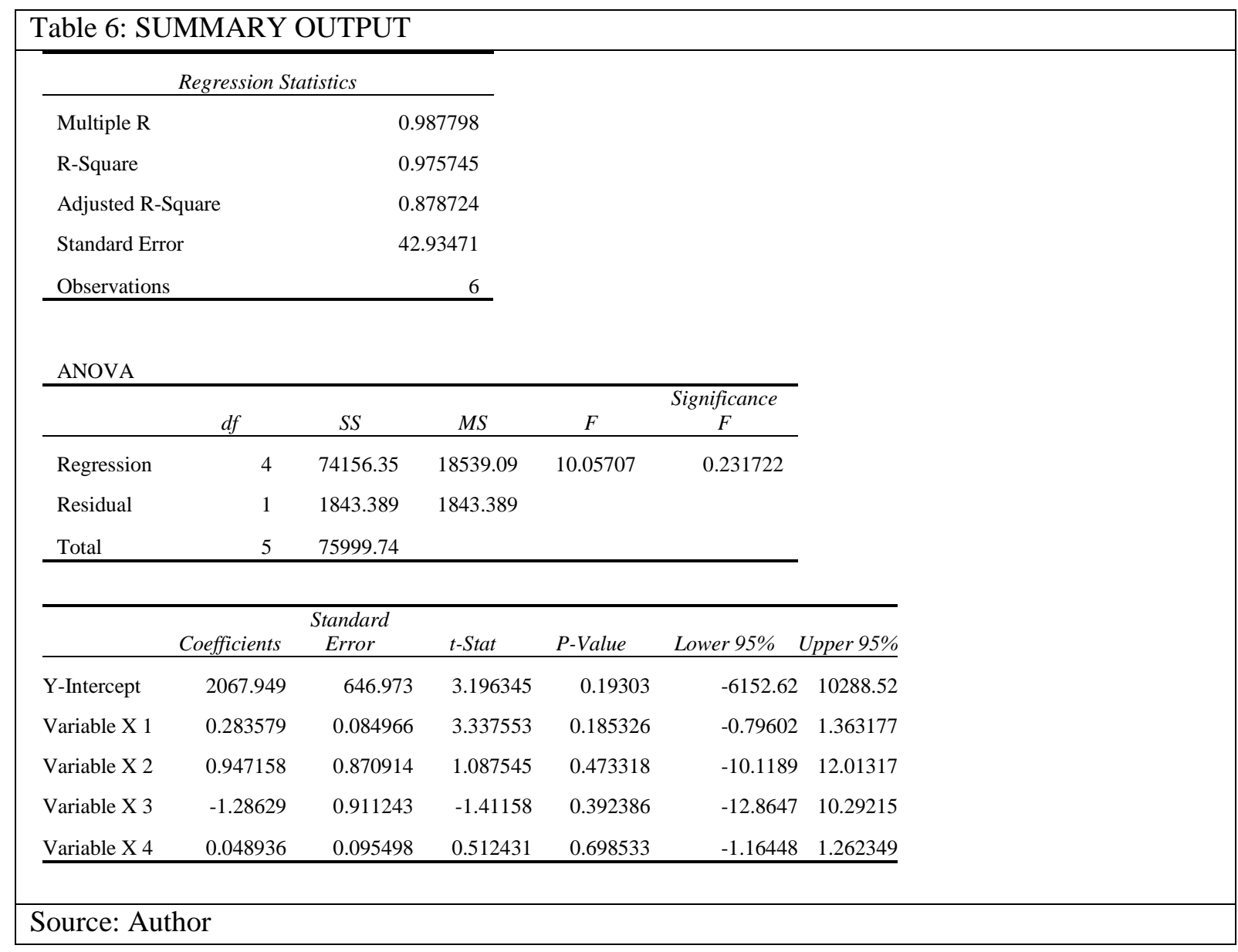

Research based on regression methods demonstrates that the reduction of these costs and an increase in profitability is reached by increasing crop area served by MSP, AWC, and providing fertilizers. 
$\mathrm{Y}=2067.94+0.28 \mathrm{X} 1+0.95 \mathrm{X} 2-1.28 \mathrm{X} 3+0.05 \mathrm{X} 4$

The model parameters demonstrate the following dependencies.

Thus, an increase of average crop area served by MSP per hectare, if other factors are constant, results in an average increase of income of only 0.28 sums. Whereas the increase of the land area served by AWC per hectare results in an increase of income of 0.95 sums. In the meantime, an increase of average crop area served by fuel and lubricant providers reduces income by a comparably high volume of 1.28 sums and the increase of land area served by mineral fertilizer providers` results in a slight increase of income of 0.05 sums.

On the basis of these data for the reduction of transaction costs and to become more profitable, it is in the farmers' interest to avoid or search for some substitution of fuel and lubricant service providers and an increase of AWC services.

The existence of transaction costs on the political level is driven by the need to use public institutions to achieve the goals and interests of rural dwellers. In particular, there is an objective necessity to represent and lobby the interests of peasantry and its individual groups to legislative and executive authorities. For some, the problems of villagers can only be solved using state institutions, laws, government decisions and programs. In these are included, for example, taxes and tax credits, government loans, grants and subsidies to agricultural producers, encouraging exports and restricting imports of food, the order of land use, public investment in social and productive infrastructure in rural areas, etc.

Participation in the political life of the country involves the institutionalization of interest groups and the formation of certain political structures - political parties, public organizations and movements, factions, etc., which requires many resources, including expenses that are the transaction costs on the political level.

At the present in Uzbekistan, the transaction costs at the political level are aimed at supporting agricultural producers. It is created as a legislative framework. In the future, based on reality, they will improve, but the main thing here is to achieve compliance of the laws at all levels of activity. This is required not only from businesses, but primarily from the executives.

\section{Conclusion}

Research shows to justify the efficiency of agriculture by the type of management and from the theoretical point of view, it is necessary to rely on neo-institutional theory. The main criteria are ownership rights and transactional costs. From this point of view, the most effective form of household with specifically local features and that are in line with the mentality of our people is dehkan-individual farms. Re-organization of the form of management from collective farms to dehkan farms resulted in increase of about $30 \%$ in effectiveness. For the further development of these forms required amendments of regulations that reflect the exact definition, transparent and respected the "rules of game" are essential.

\section{References}

Center for Economic Research. (2009). Economika Uzbekistana [Economy of Uzbekistan]. In Statisticheskiy sbornik [Economic survey data book], (p. 45-75). Tashkent, Uzbekistan: CER. 
Chayanov, A. V. (1989). Krestyanskoe khozyaistvo. Izbrannie Trudy [Farm Household. Selected Works]. Moscow, Russia: Economica.

Coase, R. (1993). Firma, rynok i pravo [The firm, the market and the law]. Moscow, Russia: Delo.

Coase, R. (2001). Priroda firmy [Nature of the Firm]. Moscow, Russia: Delo.

Dobrynin, A. \& Tarasevich, L. (2004). Economicheskaya theoriya [Economic theory] (3rd ed.). Sankt Petersburg, Russia: Peter.

Eggerson, T. (2001). Economicheskoe povedenie i instituty [Economic behavior and institutions]. Moscow, Russia: Delo.

Ministry of Agriculture and Water Resources. (2012, October 22). Pismo v Tashkentskiy Finansoviy institute [Letter to Tashkent Financial Institute from Ministry of Agricultural and Water Resources]. Registered by the Ministry of Agricultural and Water Resources No. 34-2 / 2805. Tashkent, Uzbekistan.

Nesterenko, A. M. (2002). Economica i institutionalnaya theoriya [Economics and Institutional theory]. Moscow, Russia: URSS.

The State Committee of the Republic of Uzbekistan on statistics. (2011). Selskoe khozyaystvo Uzbekistana [Agriculture of Uzbekistan]. In Ezhegodniy staticheskiy sbornik [Statistical Yearbook], (p. 19-25, 30-31, 32-41,143-170). Tashkent, Uzbekistan: UzStat.

The State Committee of the Republic of Uzbekistan on statistics. (1991). Uzbekistan v tsifrakh [Uzbekistan in figures]. In Kratkiy Statisticheskiy sbornik [Short Statistical Book], (p. 27-36). Tashkent, Uzbekistan: UzStat.

Timofeev, L. (2001). Tenevaya economika i nalogovye poteri v selskom khozyaistve [Shady economy and tax loss in Agriculture]. Voprosy Economici [Economic Questions], (p.125). Moscow, Russia: RGGU.

Umurzokov, U. P., Toshboev, A. J., \& Toshboev, A. A. (2008). Fermer khŭzhaligi ik,tisodiyoti [Farmer household economy].(p. 40) Tashkent, Uzbekistan: IQTISOD-MOLIYA.

Uzbekistan National News Agency. (1996). Economicheskiy Obzor za 1991-1996 [Economic Survey for 1991-1996]. In Uzbekistan za gody nezavisimosti [Uzbekistan for years of independence], (p. 5861, 74-75). Tashkent, Uzbekistan: UzA.

Uzbekistan National News Agency. (2011). Osnovnie tendentsii economicheskogo razvitiya Uzbekistana za gody nezavisimosti (1990-2010) I prognoz na 2011-2015 [Major trends of economic and social development of Uzbekistan for years of independence (1990-2010) and forecast for 20112015]. In Ezhegodniy statisticheskiy sbornik [Statistical Yearbook], (p. 14-15, 96-99). Tashkent, Uzbekistan: UzA. 